Research article / Научная статья

\title{
Poland and Hungary: Democratic Backsliding and the Shifting European Political Landscape
}

\section{J. Everett}

National Research University Higher School of Economics,Moscow, Russian Federation

\begin{abstract}
This study focuses on the role of Poland and Hungary in the shifting European political landscape, especially considering their recent democratic backsliding. Methodologically, the impact of domestic factors, specifically those involved in democratic backsliding, are qualitatively considered as a source of Poland and Hungary's international policy, focusing on European politics. There is significant literature available on the waves and counter waves of democratic change in the world, which is used to provide context for the cases at hand. Then, the theory of consolidation of democracy is considered, including whether Poland and Hungary were really cases of consolidated democracies. The developing Polish-Hungarian coalition, in the European context, is then considered. The two nations' role in driving the EU towards a more restrictive migration policy during the migration crisis is discussed, as is the future EU role of Poland and Hungary. The article finds that whether through extreme pressure, setting the agenda or leading the way, as during the migrant crisis, or forming a new European political grouping, Poland and Hungary look set to actively attempt to mould the EU, and European politics more generally, to their liking.
\end{abstract}

Keywords: Poland, Hungary, Democratic Backsliding, the European Union, European politics

For citation: Everett, J. (2021). Poland and Hungary: Democratic backsliding and the shifting European political landscape. RUDN Journal of Political Science, 23(3), 394-406. DOI: 10.22363/ 2313-1438-2021-23-3-394-406

\section{Польша и Венгрия: демократический откат и сдвиг политического ландшафта Европы}

\author{
Дж. Эверетт \\ Национальный исследовательский университет «Высшая школа экономики», \\ Москва, Российская Федерация
}

Аннотация. Фокусом представленной работы является роль Польши и Венгрии в изменении общеевропейского политического ландшафта, особенно с учетом предполагаемого отхода этих стран от демократических стандартов в последние годы. Используется методология количественной оценки влияния внутриполитических факторов, в особенности связанных с режимной трансформацией, на внешнюю политику Польши и Венгрии, с акцентом на их

(C) Everett J., 2021

(7) This work is licensed under a Creative Commons Attribution 4.0 International License https://creativecommons.org/licenses/by/4.0/ 
взаимоотношениях с Европейским союзом. Кейсы анализируются в контексте обширной литературы по волнам и откатам демократизации, а также в свете теории демократической консолидации. Рассматривается вопрос о том, являлись ли Польша и Венгрия полноценными консолидированными демократиями. Также исследуется становление коалиции Польши и Венгрии; обсуждаются роль этих двух стран в продвижении более жесткой иммиграционной политики во время европейского миграционного кризиса, а также будущая роль Польши и Венгрии в ЕС. Делается вывод о том, что Польша и Венгрия намерены активно влиять на устройство ЕС и европейскую политику в целом как с помощью инструментов давления, формирования повестки и лидерства, в частности во время миграционного кризиса, так и посредством создания новой политической группы влияния.

Ключевые слова: Польша, Венгрия, демократическое отступление, Европейский союз, европейская политика

Для цитирования: Everett $J$. Poland and Hungary: Democratic backsliding and the shifting European political landscape // Вестник Российского университета дружбы народов. Серия: Политология. 2021. Т. 23. № 3. С. 394-406. DOI: 10.22363/2313-1438-2021-23-3-394-406

\section{Introduction}

This article addresses the democratic backsliding of Poland and Hungary in the European context, asking what kind of role, in light of the current trajectory of democratic backsliding, Poland and Hungary may take in the shifting European political landscape. When considering the relationship between Poland, Hungary and the EU, many studies have presumed the two nation states to be mere receivers of EU policy or disciplinary action, but at the very best this image is incomplete. This article considers how Poland and Hungary may find a position from which they might actively influence the shifting European political landscape. In doing so, a qualitative approach is taken which considers the impact of domestic factors, specifically those involved in democratic backsliding, as a source of Poland and Hungary's international policy, focusing on European politics.

Initially, following the collapse of their communist regimes, Poland and Hungary were two of the pioneers of ambitious post-communist transitions, there were even hopes in Moscow that they might provide models for the rest to follow [Lévesque 1997]. The hope that they might create some kind of democratic socialism was never realised as they, and many other former communist countries, instead fully embraced the Western model, even joining the EU and NATO. What had looked like an absolute victory for the heady ideals of Western systems, such as democracy and the rule of law, appeared to have swept the region. However, in more recent times this has come to be questioned. Ironically, the pioneering Poland and Hungary have caused alarm, as some become concerned that they may be pioneers in rejecting the ideals which they had seemed to have so fully adopted.

Beyond the joint attention which they have been receiving recently, Poland and Hungary are ideal candidates for comparison as they are two countries with many similarities and markedly interwoven histories. Admittedly, all countries in the region have interwoven histories to an extent, but in the case of Poland and Hungary it is stronger than most. Once parts of large empires which covered huge amounts 
of European land and fought for one another, the 20th century experience of communism was a far cry from former glories. However, after 1989 both progressed towards democracy, free market economies and liberalism. Moreover, both have allegedly also seen some losses in that progression in recent years. The main question for consideration here is what kind of role, in light of the current trajectory of democratic backsliding, Poland and Hungary may take in the shifting European political landscape. In order to address this question, firstly whether Poland and Hungary were really consolidated democracies and how they backslid is considered. Subsequently, the Polish-Hungarian coalition is explored, then their central role in the European reaction to the migration crisis and the future EU role of Poland and Hungary is reflected upon.

\section{Transition to Consolidated Democracies}

Poland and Hungary became democracies following the rise of Gorbachev and the introduction of the policy of democratisation in the Soviet Union, several roundtable talks and free elections in central Europe, in what many considered a wave of democratisation [Huntington 1991]. Poland and Hungary were leaders in this democratisation wave, but the salient question here is were they consolidated democracies. Sage's International Encyclopaedia of Political Science describes democratic consolidation as follows: "the process of defining and firmly establishing the essential characteristics (and adjusting the secondary ones) of the structures and norms inherent in a democratic regime, which comes about also, but not exclusively, with the passage of time. Institutions, procedures, practices, customs, and routines are defined and adapted, and at the same time, the structures and regulations for the peaceful resolution of conflicts become accepted, thus strengthening the regime's legitimization" [Badie et al. 2011].

It is also explained that the consolidation of democracy has often been considered as the strengthening of a democracy, which historically meant to make it secure against the dangers of authoritarianism. However, it is stated that this changed and strengthening a democracy came to be considered more as deepening its characteristics and realising its full potential [Badie et al. 2011].

One of the most important developments in the idea of consolidated democracies was Linz and Stepan's [1996] Toward Consolidated Democracies, their definition included three main elements. These elements are as follows: behaviourally, attitudinally, and constitutionally. Linz and Stepan are also credited with popularising the term "the only game in town" [Gorokhovskaia 2017], these three elements ensure, as much as is possible, that democracy is the only game in town - that no other system approaches realistically have a chance. Behaviourally, a democratic regime is consolidated when no significant national, social, economic, political, or institutional actors within that territory spend significant resources attempting to achieve their objectives either by creating a non-democratic regime or by seceding from the state [Linz, Stepan 1996]. Attitudinally, a democratic regime is consolidated when, even in the midst of major economic problems and 
deep dissatisfaction with incumbents, a strong majority of public opinion holds the belief that democratic procedures and institutions are the most appropriate way to govern collective life, and when support for anti-system alternatives is quite small or more-or-less isolated from pro democratic forces [Linz, Stepan 1996]. Constitutionally, a democratic regime is consolidated when both governmental and nongovernmental forces accept and are subject to the resolution of conflict within the bounds of the specific laws, procedures, and institutions sanctioned by the new democratic process [Linz, Stepan 1996].

Also identified in this article are five interconnected and mutually reinforcing conditions which must be present, or created, in order for a democracy to be consolidated. The first of which is the conditions in which a free and lively civil society may be developed, which is linked with the second condition of a relatively autonomous political society. The third condition is the rule of law, which naturally must be extended to all major political actors and the entire territory of the state. Fourthly, a usable state bureaucracy must exist, allowing any new democratic government to utilise it. Fifthly, and finally, an institutionalised economic society is required [Linz, Stepan 1996]. The authors also stress the importance of a usable bureaucracy and to dismiss any thoughts of civil society versus state in some kind of confrontation. The danger of ethnic conflict and the duality of simultaneous political and economic reforms are discussed [Linz, Stepan 1996].

As early as 1998 it was assessed that for most observers Poland and Hungary had already "passed the point of no return", meaning that an authoritarian reversal in these states was considered to be unlikely [Ekiert, Kubik 1998]. The constitutional changes were the easiest to introduce, but there were concerns that financial hardship may give an opportunity to a resurgent left which could reassert authoritarianism, or facets of authoritarianism, in the newly democratic countries. However, this did not come to pass, the left lost, then won and it seemed the earlier concerns about the return of the left were misplaced and democracy managed to survive, some even argued was well served by, the loss and then victory of excommunist forces [Bozóki, Ishiyama 2002]. The left would eventually lose elections again and the consistent changing of power furthered the idea that they democracies had passed the point of no return. According to research by Szawie, undertaken a decade after Ekiert and Kubik had already concluded that Poland had passed the point of no return: "The analyses suggest that Polish democracy is consolidated, stable and persistent. However, support for democratic government is hardly enthusiastic" [Szawiel 2009]. Overall, some concerns lingered, but most respected opinions considered Poland and Hungary to be consolidated democracies, or a considerable way down the path to consolidation. In light of such judgements, the subsequent backsliding seems very unexpected. The next section outlines the theory of democratic backsliding and how it occurred in Poland and Hungary.

\section{From Consolidated to Backsliding Democracies}

The breadth of the concept of democratic backsliding is important in understanding the concept itself, as it incorporates so many ideas and notions. In its 
most basic form, it refers to the state-led debilitation or elimination of any of the political institutions that sustain an existing democracy [Bermeo 2016]. However, due to the myriad of political institutions which sustain democracy, the term embraces multiple processes [Bermeo 2016]. Another important element of backsliding is the pace at which it occurs, with it involving "relatively fine-grained degrees of change" [Waldner, Lust 2018]. It is also important to note that, as backsliding "entails a deterioration of qualities associated with democratic governance", it can occur in different regime types; in democratic regimes, it is a decline in the quality of democracy; in autocracies, it is a decline in democratic qualities of governance [Waldner, Lust 2018]. Bermeo [2016] identified six major varieties of democratic backsliding:

1) open-ended coups d'état

2) promissory coups

3) executive coups

4) executive aggrandisement

5) election-day vote fraud

6) strategic harassment and manipulation

In modern times, open-ended coups d'état, executive coups and election-day vote fraud are being replaced by promissory coups, executive aggrandisement and strategic harassment and manipulation.

Since the rise of Fidesz in Hungary, from 2010, and the Law and Justice party (PiS) in Poland, from 2015, there has been much criticism directed at the two governments. By 2020, Hungary had been said to have clearly crossed the line and left liberal democracy behind, while the PiS government in Poland was said to have gone far down a similar track [Bakke, Sitter 2020]. It has been stated that the governments of the two countries have "led both countries to levels of democratic backsliding that are considered intolerable by the EU" [Holesch, Kyriazi 2020]. Hungary has been termed an authoritarian regime, while PiS have dramatically eroded liberal democracy [Vachudova 2020]. Hungary was downgraded to partly free by Freedom House due to Fidesz's imposition of restrictions or assertion of control over the opposition, the media, religious groups, academia, NGOs, the courts, asylum seekers, and the private sector since 2010 [Bakke, Sitter 2020]. The employment of ethnopopulism, defined as the intertwining of the defence of "the people" with the defence of an ethnicity, culture, nation, religion and/or race, in both countries is significant, with it representing both a strategy for winning votes and for concentrating power [Vachudova 2020].

The mere fact that both Poland and Hungary have experienced state-led debilitation or elimination of any of the political institutions that sustain an existing democracy and a deterioration of qualities associated with democratic governance does not mean that the two are exactly the same. Firstly, the exact techniques have somewhat differed; secondly, the presence of democratic backsliding does not mean that the destination of said backsliding is the same. The specific techniques utilised in Poland have resulted in the country becoming one of the most polarised countries in the EU, along religious and gender and sexual orientation, and have led to many 
calling the Polish form of backsliding conservative autocracy [Magyar, Madlovics 2020], Zeller ${ }^{1}$. Others have spoken of the conservative modernisation strategy of PiS [Jasiecki 2018]. Hungary, on the other hand, has been presented as a case of patronal autocracy [Magyar, Madlovics 2020] or even a paradigmatic case of the mafia state [Magyar, Vásárhelyi 2017].

The fact that some backsliding has occurred seems to largely be beyond doubt; however, the specific changes which have been undertaken requires some explanation. According to Levitsky and Ziblatt [2018] elected autocrats:

'subvert democracy - packing and 'weaponizing' the courts and other neutral agencies, buying off the media and the private sector [or bullying them into silence], and rewriting the rules of politics to tilt the playing field against opponents. The tragic paradox of the electoral route to authoritarianism is that democracy's assassins use the very institutions of democracy - gradually, subtly, and even legally - to kill it."

All of these methods can be seen to be employed in Poland and Hungary. Fidesz and PiS both targeted state-run media, filling editorial boards and oversight organs with appointees loyal to them, resulting in what some called "a veritable government propaganda machine" [Bakke, Sitter 2020]. Journalistic freedom is often considered an important bastion of freedom of speech. However, control of the media has been central to the policies of both Orbán and Kaczyński [Sata, Karolewski 2020]. In Hungary media legislation was adopted in order to correct a perceived leftist bias, added to this was the appointment system which effectively gave the government de facto control over the Media Council and Hungary's public service media outlets: national TV, radio stations and the national news service. Licencing for private media outlets and the threat of sanctions from the Media Council for content which is not considered balanced, accurate, thorough objective and responsible, further curtailed journalistic freedom [Sata, Karolewski 2020]. PiS focused on replacing leading personnel in public radio and $T V$, enacting controversial laws which enabled the Minister of Treasury to directly appoint the heads of public TV and radio. In a move which circumvented the National Broadcasting Council, a constitutional institution, to guarantee independent information in state-owned media [Sata, Karolewski 2020].

Significant backsliding in the area of the rule of law also occurred. In both Poland and Hungary there were attacks on checks and balances, the independence of the judiciary, and control of public administration [Bakke, Sitter 2020]. Poland and Hungary have both utilised the twin concepts of constitutional identity and constitutional pluralism, notable instances include Hungary blatantly violating the EU asylum acquis and refusing to recognise the primacy of EU law in this domain, or Poland attacking the independence of the judiciary, claiming that such matters fall within the exclusive bounds of its authority and citing scholars of constitutional pluralism and the EU's "national identity clause" [Kelemen, Pech 2019].

\footnotetext{
${ }^{1}$ Zeller, M.C. (2020, September 1). Poland is moving further towards autocracy. OpenDemocracy. Retrieved April 5, 2021, from https://www.opendemocracy.net/en/global-extremes/poland-movingfurther-towards-autocracy/
} 
Backsliding in the area of free and fair elections also took place, mainly affecting the rules of elections, including financing and specific procedures. Fidesz undertook reforms in 2011, the changes were extreme in both their unilateral nature, but also in the tailor-made nature of the electoral reform [Bakke, Sitter 2020]. The OSCE criticised the 2014 and 2018 Hungarian election as free but not fair [Bakke, Sitter 2020]. Fidesz overhauled Hungary's electoral system in repeated modifications to favour themselves, manipulating advertising and campaigning rules to benefit his party, encouraging the creation of fake-parties to split the antiFidesz vote, engaging in gerrymandering and co-opting the State Audit Office [Sata, Karolewski 2020]. PiS lacked the constitutional changing majority of Fidesz, cancelling a proposed electoral law similar to the Hungarian one which was successfully enacted. However, they do regularly employ public institutions as weapons against the opposition to limit political competition, with PiS controlled tax authorities or district attorneys harassing opposition politicians [Sata, Karolewski 2020].

Despite having once been considered consolidated democracies, both Poland and Hungary have been observed to have experienced democratic backsliding, with ethnopopulism at play. This deployment of ethnopopulism was always likely to put the two nations on a collision course with the pluralist multi-ethnic European Union. Such conflict was not shied away from, rather it was embraced. In the rhetoric of Orbán and Kaczyński, the EU is equated with "the corrupt elite" in conflict with the "pure people", in other words, the Hungarians and Poles [Csehi, Zgut 2021]. The notion of popular sovereignty is also important, as is the antiimperialist feelings so heavily present in the politics of the two countries [Csehi, Zgut 2021].

This section has considered how Poland and Hungary moved from consolidated democracies to prime examples of democratic backsliding. The concept of democratic backsliding was outlined, before considering the trajectories and techniques of Poland and Hungary. So far, attention has been paid to the domestic situation of the two. However, both are members of multiple international organisations; arguably, the most important of which being the European Union. Therefore, the subsequent sections consider the two in this context, discussing the Polish-Hungarian coalition, their role in the migration crisis and their future role within the EU.

\section{The Polish-Hungarian Coalition}

The fact that there has been democratic backsliding in Poland and Hungary is, at this stage, well documented, even the exact techniques used to achieve this have been well documented. The fact that there have been different typologies applied to the kind of regimes which have developed in Poland and Hungary has been noted, but that has not prevented the two countries working together to form, what is called here, a Polish-Hungarian coalition. The term Polish-Hungarian coalition has been used by Holesch and Kyriazi [2020], but others have preferred to use the term 
"illiberal bloc" [Nyyssönen 2018]. Other terms may well be applied to the phenomenon of Poland and Hungary's close relationship, which has increasing importance for the international and, especially, European arena.

In general, there has begun to be an acknowledgement that the discussion regarding the two must move beyond democratic backsliding to consider broader implications. However, few have taken note of the pressure which Poland and Hungary have applied and the successes they have already experienced. Holesch and Kyriazi [2020] did note the role of the Hungarian-Polish coalition in the European Union. They found that the coalition worked together to provide mutual protection within the supranational arena, especially with the aim of limiting the EU's sanctioning capacities [Holesch, Kyriazi 2020]. This kind of "defensive" strategy of the coalition, working together to protect each other from the types of punishments the EU may hand out are well-known. However, this article attempts to go beyond this more traditional view to consider how the two might work together towards more proactive goals.

Only indirectly affecting the EU are two more central factors in the PolishHungarian coalition: learning and legitimation. The transfer of backsliding measures and practices between the two nations is to be expected and can be seen in various areas of the two nations [Holesch, Kyriazi 2020]. Domestic legitimation can be greatly strengthened by the political backing of a key international ally; indeed, endorsement on the international level helps to cast the government's controversial actions as normal and justified at home, something which has occurred between Poland and Hungary [Holesch, Kyriazi 2020].

The pairing of Poland and Hungary are perhaps predisposition to coalition, the phrases "Pole and Hungarian cousins be" in Polish and "Pole and Hungarian, two good friends" in Hungarian illustrate the closeness of the two nations [Nyyssönen 2018]. In such a context, the international legitimation of a close ally, a cousin even, is likely to be particularly effective. Shared history is often stressed too, with the year 1848, and particularly one man, general Jósef Bem, of central importance [Nyyssönen 2018]. Furthermore, both desire to be different, stress their own paths of history, search for prestige, and consider all this more important than the current Western criticism of democracy and the rule of law [Nyyssönen 2018].

As previously noted, the governments of the two countries have been said to have "led both countries to levels of democratic backsliding that are considered intolerable by the EU" [Holesch, Kyriazi 2020]. Furthermore, the EU seems to have woken up to the danger, with the Commission beginning to explore new policy tools for dealing with rule-of-law violations, including withholding EU funding [Bakke, Sitter 2020]. On the other hand, the EU faces an intervention paradox, where sanctions, if not blocked by the coalition, may curb illiberalism or may be seen as interference in the sovereign political space of member states, triggering a powerful nationalist backlash [Öniş, Kutlay 2020]. Meanwhile, far from turning the tide it seems that the coalition may well spread its ideology abroad, perhaps within the Western Balkans where Orbán's use of soft power has been noted [Holesch, Kyriazi 2020].

The possible impact of the Polish-Hungarian coalition goes far beyond their neighbours in the Western Balkans or even the post-communist area of Europe. 
There is perhaps an element of snobbery, from the scholarship and politicians alike, in how the backsliding in Poland and Hungary is addressed within the EU context. Perhaps this can somewhat be explained by the prevailing view of post-communist transitions being the convergence, or sometimes even the catching up, of postcommunist nations with those of Western Europe. It is conceivable that some view the EU project as one to be steered and controlled by the traditional nations of the Union. However, politics rarely transpires as such. Instead, Poland and Hungary have every chance of making waves on the EU stage, of influencing policy directions on the EU level and taking a significant role in shaping the shifting European political landscape.

\section{The Migration Crisis}

The migrant crisis in Europe was the first time that Poland and Hungary had a clear impact on European level politics since their backsliding had begun. The refugee crisis led to public discussions about the threat that Muslim refugees pose to the Christian identity of the continent, especially in the new accession countries in Central Europe, in what some have called Islamophobia without Muslims [Goździak, Márton 2018]. In Poland the migration crisis was painted as the manifestation of an incompetent political elite that acted against the interest of the Polish people, potential mandatory relocation quotas were opposed and Kaczyński spoke of "external oppression" and the "breaking of the sovereignty of the people" [Csehi, Zgut 2021]. In Hungary, Orbán spoke of the loss of a "common European homeland" and explicitly blamed the political, economic and intellectual leaders for this loss, "who are trying to reshape Europe against the will of the people of Europe" [Csehi, Zgut 2021].

The narratives which dominated the Polish and Hungarian press painted the recent influx of refugees seeking safety in Europe as a "raid", a "conquest" and "penetration", as well as asserting that Muslims will combat Europe not only with terrorism but also with the uteruses of their women, who will bear enough children to outnumber native Poles and Hungarians [Goździak, Márton 2018]. Such rhetoric easily dovetailed with the existing views being disseminated by the governments of Poland and Hungary, which painted the EU as out of touch elitists. These out of touch elitists were pushing for the destruction and desecuritisation of Poland and Hungary, as well as Polish and Hungarian society, or so went the rhetoric.

The events of the migration crisis were developing as Poland and Hungary voiced their displeasure with Brussels and further leaned into their form of populism. Towards the end of 2015, approximately 10,000 people were arriving on the Greek islands every day and the European Council initiated a joint action plan with Turkey, which would eventually become the EU-Turkey agreement, implemented in March 2016 [Baldwin-Edwards et al. 2019]. The explicitly stated objective was to reduce the number of refugees and other migrants arriving in EU territory, significant transfers of financial assistance were made, in March 2016, all the Balkan borders were closed for asylum seekers wishing to exit Greece and the eastern border with Turkey was formally closed [Baldwin-Edwards et al. 2019]. The 
EU-Turkey agreement created a cut-off point of 20 March, after this for every Syrian returned from Greece another would be resettled directly from Turkey to the EU, Turkey was to take measures to prevent all irregular migration from Turkey to the EU and funding of $€ 3$ bn from the Facility for Refugees in Turkey would be available, with another potential $€ 3$ bn by the end of 2018 [Baldwin-Edwards et al. 2019].

Many felt that the EU's response was a dereliction of duty and an abandoning of European values. However, without entering into such a contentious debate, so fraught with potential difficulties and points of dispute, it is sufficient for this paper to note the importance of the pressure applied by Poland and Hungary. Indeed, it is notable that during the height of the crisis "one by one, Greece's western neighbours followed Hungary's example and closed their borders" [Baldwin-Edwards et al. 2019]. The role of other Eurosceptic, and often migrant-sceptic countries, such as the UK, should not be ignored. Nevertheless, it seems that two nations which had only entered the European Union in 2004 had employed such pressure on Brussels so as to drastically alter the whole unions policy direction. Such impact from two democratically backsliding nations prompts the question of what the future role of Poland and Hungary may be in European politics.

\section{The Future EU Role of Poland and Hungary}

Even while Poland and Hungary were successfully influencing the policy direction of the EU, there were signs that not all was well for Poland and Hungary in the European community. The European People's Party (EPP) suspended the membership of Fidesz on the grounds of democratic backsliding [Bakke, Sitter 2020]. The triggering of the Article 7 sanctions procedure against Hungary in the European Parliament resulted in Orbán further sharpening the distinction between "the corrupt EU" and "the Hungarians", but also defending both Poland and Hungary from the EU on anti-imperialist grounds [Csehi, Zgut 2021]. The way the anti-elitist and anti-EU populism was being utilised during the democratic backsliding in the two countries was always likely to draw attention and potential consequences from the supranational level. What, then, is the future of Poland and Hungary in the EU and what role will they play in that union?

Poland and Hungary, as well as their interdependence, have been said to form the origin and the core of the current "illiberal bloc" [Nyyssönen 2018]. The two governments have shown no intentions of passively accepting the punishments the EU may direct against them or the policy direction which the rest of the continent may try to steer them down. This is part of a broader observable trend in which heavily nationalist and illiberal leaders from Putin to Trump, from Orban to Erdoğan, from Le Pen to Salvini, benefit from one another's existence [Öniş, Kutlay 2020]. They try to maximise the mutual benefits, forming alliances and crosscutting coalitions to advance their cause rather than remaining on the receiving end of the hegemonic contest over prevalent norms in a shifting international order [Öniş, Kutlay 2020]. How could this affect the future of the EU?

The clearest sign of what the future could hold may well be the plan between Orbán and Polish ally Morawiecki, as well as Salvini, leader of Italy’s rightist 
League party, to create a new European political grouping ${ }^{2}$, suggesting that these countries will seek to play an active role in shaping the shifting European political landscape. It seems that Orbán and Kaczyński are not necessarily interested in copying the Brexit strategy, Orbán especially wants to be an integral part of a process in which the EU is transformed from within and evolved into a different kind of entity [Öniş, Kutlay 2020]. It has been speculated that Orbán desires an EU which is mono-cultural and anti-immigrant, which has closed borders and is constituted by patriots instead of cosmopolitans, where Christian culture dominates instead of a multicultural mishmash [Öniş, Kutlay 2020]. Given how both have desired to be different, it is easy to see how such a vision would appeal to many within Poland, undoubtedly a majority within PiS, but the appeal may be broader still - as meetings with Salvini indicate.

Previous attempts to unify have failed, in no small part due to differing views on relations with Russia; Poland, and PiS especially, hold quite Russophobic views. On the other hand, Orbán and Fidesz have been against EU sanctions on Russia, use Russian oil, gas and nuclear power, and became the first EU country to use a Russian vaccine for COVID-19. Salvini and some other potential members of the new group are pro-Russian and this may cause problems for the future alliance ${ }^{3}$. Nevertheless, Fidesz are no longer part of the mainstream conservative European People's Party, with Orbán noting that many Europeans reject immigration and multiculturalism, prefer a traditional family model and want to protect their national identity and consider national authority superior to European directives, yet these voters have fragmented representation in Europe, a situation he hoped to resolve with this new alliance ${ }^{4}$.

Significant barriers remain to such an alliance, for example, in 2015 the Polish and Hungarian Prime Ministers traded history lessons regarding Russian relations [Nyyssönen 2018]. This situation may worsen in the future, the growing tendency for the Russophobia of PiS to stray into pure delusional conspiracy theory promotion, as with the repeated claims that the Kaczyński plane crash of 2010 was actually a Russian assassination, may well prove to represent too significant a hurdle to be surpassed in the search for a functioning European political grouping. Furthermore, the broad Polish opposition to Nord Stream 2 may cause significant issues for the country, unless as with the migration crisis they once again find themselves on the victorious side of the policy debate. There is a possibility that this may well be the case, although the exit of the UK from the EU may make their task somewhat more difficult. Nevertheless, Poland and Hungary are seeking to create a new European political grouping, a clear sign that they seek a platform to actively shape European politics and have no intention of passively accepting what the EU decrees.

\footnotetext{
${ }^{2}$ Dunai, M., \& Plucinska, J. (2021, April 1). Hungary, Poland, Italy leaders seek new European right-wing core. Reuters. Retrieved April 5, 2021, from https://www.reuters.com/article/eu-politics-hungary-poland-italy-idUSL8N2LU3GM

${ }^{3}$ Ibid.

${ }^{4}$ Ibid.
} 


\section{Conclusion}

This article has addressed the democratic backsliding of Poland and Hungary, asking what kind of role, in light of the current trajectory of democratic backsliding, Poland and Hungary may take in the shifting European political landscape. In order to address this question, firstly whether Poland and Hungary were really consolidated democracies and how they backslid was considered. Subsequently, the Polish-Hungarian coalition was explored, then their central role in the European reaction to the migration crisis and the future EU role of Poland and Hungary were reflected upon. The transition to democracy has been conceptualised in different ways, but many considered Poland and Hungary to be consolidated democracies. However, the two nations then experienced democratic backsliding. The backsliding saw the rule of law eroded, the media landscape and rules governing elections changed to suit the ruling parties, especially in Hungary. Such changes, along with the ethnopopulism which have brought Fidesz and PiS to power, have put the two countries on a collision course with the EU.

The changes in these two EU member states have resulted in speculation that they may face various consequences. Indeed, article 7 was triggered in the case of Hungary, who also saw The European People's Party (EPP) suspend the membership of Fidesz on the grounds of democratic backsliding. However, amid such issues the two have joined together to provide mutual protection within the supranational arena, especially with the aim of limiting the EU's sanctioning capacities, they also played a major role in shifting the EU's policy direction during the migration crisis. Furthermore, Orbán, Morawiecki and Salvini are working on the creation of a new European political grouping, which suggests that these countries will seek to play an active role in shaping the shifting European political landscape. When considering the relationship between Poland, Hungary and the EU, many have presumed the two nation states to merely be receivers of EU policy or disciplinary action, but at the very best this image is incomplete. Whether through extreme pressure, setting the agenda or leading the way, as during the migrant crisis, or forming a new European political grouping, Poland and Hungary look set to influence the shifting European political landscape.

Received / Поступила в редакцию: 16.04.2021 Accepted / Принята к публикации: 12.05.2021

\section{References}

Badie, B., Berg-Schlosser, D., \& Morlino, L. (Eds.). (2011). International encyclopedia of political science. SAGE Publications.

Bakke, E., \& Sitter, N. (2020). The EU's enfants terribles: Democratic backsliding in Central Europe since 2010. Perspectives on Politics, 1-16.

Baldwin-Edwards, M., Blitz, B.K., \& Crawley, H. (2019). The politics of evidence-based policy in Europe's 'migration crisis.' Taylor, Francis.

Bermeo, N. (2016). On democratic backsliding. Journal of Democracy, 27(1), 5-19.

Bozóki, A., \& Ishiyama, J.T. (Eds.). (2002). The communist successor parties of Central and Eastern Europe. Routledge. 
Csehi, R., \& Zgut, E. (2021). 'We won't let Brussels dictate us': Eurosceptic populism in Hungary and Poland. European Politics and Society, 22(1), 53-68.

Ekiert, G., \& Kubik, J. (1998). Contentious Politics in New Democracies: East Germany, Hungary, Poland, and Slovakia, 1989-93. World Politics, 50(4), 547-581. JSTOR.

Gorokhovskaia, Y. (2017). Democratic consolidation [Data set]. Oxford University Press. https://doi.org/10.1093/obo/9780199756223-0224

Goździak, E.M., \& Márton, P. (2018). Where the wild things are: Fear of Islam and the antirefugee rhetoric in Hungary and in Poland. Central and Eastern European Migration Review, $7(2), 125-151$.

Holesch, A., \& Kyriazi, A. (2020). Democratic backsliding in the European Union: The role of the Hungarian-Polish coalition. East European Politics, 1-20.

Huntington, S.P. (1991). Democracy's Third Wave. Journal of Democracy, 2(2), 12-34. https://doi.org/ 10.1353/jod.1991.0016

Gunitsky, S. (2018). Democratic Waves in Historical Perspective. Perspectives on Politics, 16(3), 634-651. https://doi.org/10.1017/S1537592718001044

Jasiecki, K. (2018). "Conservative modernization" and the rise of law and justice in Poland. In New conservatives in Russia and East Central Europe (pp. 130-153). Routledge.

Kelemen, R.D., \& Pech, L. (2019). The uses and abuses of constitutional pluralism: Undermining the rule of law in the name of constitutional identity in Hungary and Poland. Cambridge Yearbook of European Legal Studies, 21, 59-74.

Lévesque, J. (1997). The enigma of 1989: The USSR and the liberation of Eastern Europe. University of California Press.

Levitsky, S., \& Ziblatt, D. (2018). How democracies die (First edition). Crown.

Linz, J.J., \& Stepan, A.C. (1996). Toward consolidated democracies. Journal of Democracy, 7(2), $14-33$.

Magyar, B., \& Madlovics, B. (2020). The anatomy of post-communist regimes: A conceptual framework. Central European University Press.

Magyar, B., \& Vásárhelyi, J. (Eds.). (2017). Twenty-five sides of a post-communist Mafia state. CEU Press.

Nyyssönen, H. (2018). The East is different, isn't it?-Poland and Hungary in search of prestige. Journal of Contemporary European Studies, 26(3), 258-269.

Öniş, Z., \& Kutlay, M. (2020). Reverse transformation? Global shifts, the core-periphery divide and the future of the EU. Journal of Contemporary European Studies, 28(2), 197-215.

Sata, R., \& Karolewski, I.P. (2020). Caesarean politics in Hungary and Poland. East European Politics, 36(2), 206-225.

Szawiel, T. (2009). Democratic consolidation in Poland: Support for democracy, civil society and the party system. Polish Sociological Review, 168, 483-506. JSTOR.

Vachudova, A. (2020). Ethnopopulism and democratic backsliding in Central Europe. East European Politics, 36(3), 318-340.

Waldner, D., \& Lust, E. (2018). Unwelcome change: Coming to terms with democratic backsliding. Annual Review of Political Science, 21(1), 93-113. https://doi.org/10.1146/annurev-polisci050517-114628

About the author:

Judas Everett - Postgraduate of the Doctoral School of Political Science, National Research University Higher School of Economics (e-mail: judas.everett@gmail.com) (ORCID ID: 00000003-0794-0153).

\section{Сведения об авторе:}

Джудас Эверетт - аспирант Аспирантской школы по политическим наукам Национального исследовательского университета «Высшая школа экономики» (e-mail: judas.everett@gmail.com) (ORCID ID: 0000-0003-0794-0153). 